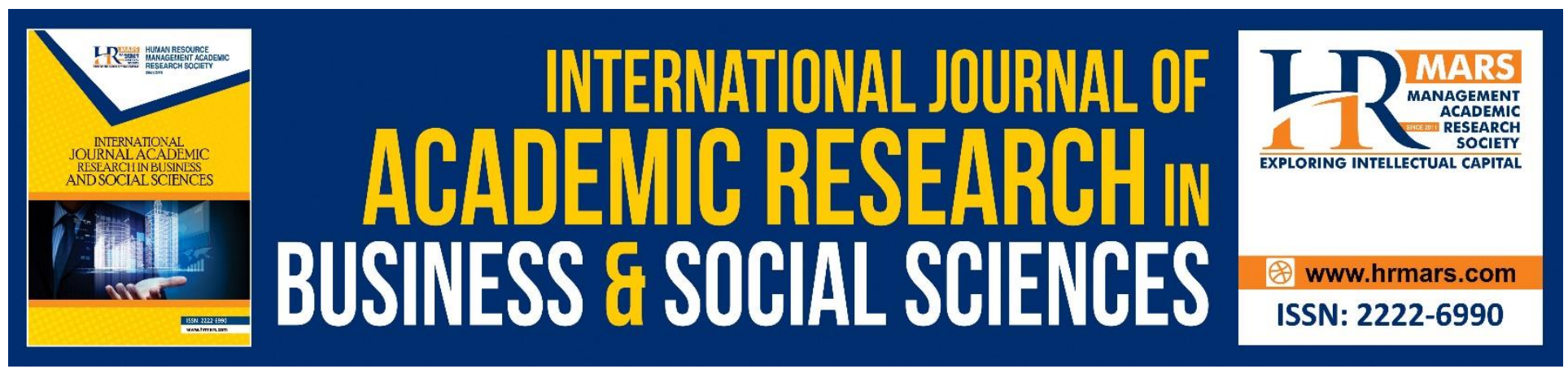

\title{
Adoption of IFRS in Nigeria: Challenges and the Way Forward
} John Onyemaechi Odo

To Link this Article: http://dx.doi.org/10.6007/IJARBSS/v8-i8/4493

DOI: $\quad 10.6007 /$ IJARBSS/v8-i8/4493

Received: 26 July 2018, Revised: 23 August 2018, Accepted: 29 August 2018

Published Online: 09 September 2018

In-Text Citation: (Odo, 2018)

To Cite this Article: Odo, J. O. (2018). Adoption of IFRS in Nigeria: Challenges and the Way Forward. International Journal of Academic Research in Business and Social Sciences, 8(8), 426-440.

Copyright: (c) 2018 The Author(s)

Published by Human Resource Management Academic Research Society (www.hrmars.com)

This article is published under the Creative Commons Attribution (CC BY 4.0) license. Anyone may reproduce, distribute, translate and create derivative works of this article (for both commercial and non-commercial purposes), subject to full attribution to the original publication and authors. The full terms of this license may be seen at: http://creativecommons.org/licences/by/4.0/legalcode

Vol. 8, No. 8, August 2018, Pg. 426 - 440

Full Terms \& Conditions of access and use can be found at http://hrmars.com/index.php/pages/detail/publication-ethics 


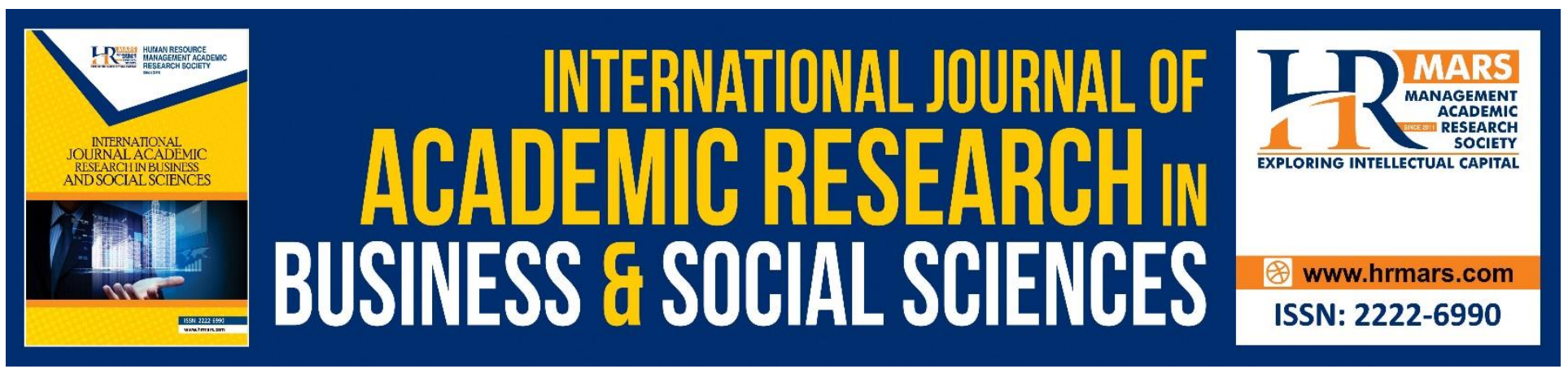

\title{
Adoption of IFRS in Nigeria: Challenges and the Way Forward
}

\author{
John Onyemaechi Odo, Ph.D \\ Department of Accounting and Finance, Godfrey Okoye University, Enugu, Enugu state, Nigeria \\ Email: jesobueze@yahoo.com
}

\begin{abstract}
The purpose of this paper is to examine the adoption of International Financial Reporting standards (IFRSs) in Nigeria, its inherent challenges and suggest ways forward to realize the expected benefits of its adoption. The paper brought to limelight the history, and challenges encountered during the adoption and the ways to move forward so as to reap the benefits of IFRS adoption. The study employed review and trend analytical approach to discover that IFRS adoption improved the quality of financial statements presentation, moreso it was discovered that IFRS adoption attracted a lot of benefits to the country. Such includes the increase in foreign direct investment inflow, uniformity of accounting language which makes comparison of financial statements possible. That notwithstanding the adoption faced a lot of challenges which can be overcome by strengthening professional accounting education and training, raising awareness of professional regulators and preparers to improve the knowledge gap and providing adequate resources to support the sustainable implementation of IFRS.
\end{abstract}

Keywords: Adoption, IFRS, Nigeria, Challenges, Way forward

\section{Introduction}

The accounting profession in Nigeria received a formal reckoning in the mid-1960's (Chibuke; 2008). During that period, Nigerian accountants, mostly trained by professional accounting bodies in the United Kingdom came together and formed a professional accounting body that is responsible for the training of accountants in Nigeria and fostering the development of the profession in the country. Presently, however, two notable professional accounting bodies carry out such functions concurrently. These bodies pay much attention to the teaching of technical and practical aspects of accounting. The two accounting bodies in Nigeria are the Institute of Chartered Accountants of Nigeria (ICAN) and the Association of National Accountants of Nigeria (ANAN). They are in essence self-regulating, and both membership elect governing council members. There is no separate statutory body for the audit profession while ICAN acts as an examining body for awarding Chartered Accountant Certification and as the licensing authority for members engaged in public auditing practices ANAN advances the science of Accountancy through its unique collegiate system. Members of ICAN and ANAN are recognized as members of the International Federation of Accountants (IFAC) 
INTERNATIONAL JOURNAL OF ACADEMIC RESEARCH IN BUSINESS AND SOCIAL SCIENCES Vol. 8, No. 8, August 2018, E-ISSN: 2222-6990 @ 2018 HRMARS

and have strong International foundation and relationship. ICAN members dominate accounting and auditing services in the private sector while ANAN members are mostly employed in the public sector.

The first recognized attempt towards standard convergence was the proposal by the professional accountancy bodies in Canada, United Kingdom, and the United States to create the Accountants International Study Group (AISG) in 1966. The primary aim of its formation was to develop studies of accounting and auditing practices in the three regions.

Meanwhile, at the $40^{\text {th }}$ World Congress of Accountants in Sydney held in 1972, Sir Henry Benson put forward the proposal for the setting up of the International Accounting Standards Committee (IASC). After due deliberations by the three AISG countries and other representatives of the professional accountancy bodies present, IASC was established in 1973, with Sir Henry Benson and Paul Rosenfield as its first Chairman and Secretary respectively. The main objective of IASC formation was to develop a single set of high standard quality International Accounting Standards (IASs). All listed companies in Europe were mandated by the European Commission to adopt IASs or the IFRS from 2005 (Odia \& Ogiedu, 2013)

It is worthy to note that financial statements which these standards are set to guide not only state the financial position of an organization, but provides other information such as the value added changes in equity and cash flows of a business entity within a specified period (Iyoha \& Faboyede, 2011). Such statements provide information that is useful to the wide range of users as they help to make informed economic decisions. Financial reports can be useful if they represent the 'economic substance' of an organization in terms of relevance, reliability, comparability and aids interpretation (Penman, 1984). Similarly, Ahmed (2003) state that useful accounting information derived from qualitative financial reports help in efficient allocation of resources by reducing dissemination of information, lop-sidedness and improving pricing of securities. To achieve such a high quality financial report, some accounting standards have to be put in place so as to encourage uniformity, reliability and comparability. It is the opinion of the Accounting bodies that the implementation of IFRS would reduce irregularity and strengthen the communication link among the stakeholders. Other notable advantages of IFRS implementation include the reduction in cost of preparing different version of financial statements where an organization is a multi-national entity. (Healy \& Palepu, 2001).

Evidently, achieving a globalized capital market requires a unified global accounting reporting and disclosure of set of standards. In line with this, the International Accounting Standard Board adopted the IFRS framework on 1 April, 2001. The standards were adopted by over 90 countries around the world. IFRS was established and approved by the IASB. The goals of the IFRS foundation and the IASB is to develop in the public interest a single set of high quality understandable, enforceable and globally acceptable financial reporting standards based upon clearly articulated principles .

The introduction of IFRS came to the front burner in Nigeria by 28 July 2010, when the Nigeria Federal Executive Council approved $1^{\text {st }}$ January 2012 as the effective date for convergence of accounting standards in Nigeria with International Financial Reporting Standards (IFRS). The Council further directed the Nigerian Accounting Standard Board (NASB), under the supervision of the Nigerian Federal Ministry of Commerce and Industry to take further necessary action to give effect to the council's approval. On $3^{\text {rd }}$ September, the Nigerian Accounting Standard Board (NASB) announced a staged implementation of IFRS as follows: publicly listed entities and significant public interest entities are expected to implement IFRS by January, $1^{\text {st }} 2012$. Other public interest entities are 
INTERNATIONAL JOURNAL OF ACADEMIC RESEARCH IN BUSINESS AND SOCIAL SCIENCES

Vol. 8, No. 8, August 2018, E-ISSN: 2222-6990 @ 2018 HRMARS

expected to implement IFRS by January $1^{\text {st }} 2013$ while small and medium sized entities are expected to implement same by January 2014. This staged implementation outlined by the NASB was approved by the Federal Executive Council (FEC) on 28 July, 2010(Okpala, 2012).

Before the adoption of IFRS in Nigeria, there was legal and regulatory framework of accounting in respect to preparation of financial report in Nigeria. The Company and Allied Matter Act (CAMA'90) prescribe some format and content of company financial statement disclosure requirements and auditing. It requires that the financial statement of all corporate organisations comply and adhere with the Statement of Accounting Standards (SAS) issued from time to time by the Nigerian Accounting Standard Board (NASB). This also requires that audit be carried out in accordance with the General Auditing Standards. Therefore, the adoption of IFRS in Nigeria launched in September, 2010 by the then Minister of Commerce and Industry was an advancement to already existing regulatory structure.

\section{Literature Review}

\section{International Financial Reporting Standards}

The international financial reporting standards (IFRS) consist of standards issued by International Accounting Standards Board from $1^{\text {st }}$ April, 2001. The scope of IFRS captures the Standards and interpretation adopted by the International Accounting Standards Board (IASB). The International Accounting Standards Board is a successor of International Accounting Standards Committee which was originally established in 1973. The standards promulgated by the International Accounting Standard Committee (IASC) prior to $1^{\text {st }}$ April 2001 are referred to as International Accounting Standard (IAS). After the formation of IASB in 2001, it took over all the interpretations given by the Standard Interpretation Committee (SIC) before the formation of the International Financial Reporting Interpretation Committee (IFRIC). Such standards and interpretations taken over were either amended or repelled, hence IASB currently accepted standards including all the following: Standards Promulgated from $1^{\text {st }}$ April 2001 IFRS; International Accounting Standards (IAS) which are Standards promulgated prior to $1^{\text {st }}$ April 2001 not yet amended or repelled; standards interpretation committee (SIC) Interpretations given by Standard Interpretation Committee prior to $1^{\text {st }}$ April 2001 not yet repelled and International financial reporting committee (IFRIC) Interpretations given by the International Financial Reporting Interpretation Committee

Aghator \& Adeyemi (2009) opined that International Financial Reporting standards (IFRS) refers to a series of accounting pronouncements published by the international Accounting Standards Board to help prepares of financial statements throughout the globe produce and present high quality, comparable and transparent financial statements.

Nwabueze, (2012) as in Ezeani \& Oladele (2012) opined that research into the financial regulatory bodies has been scanty over the decades. Few authors have acknowledged that adherence to financial reporting standards requires an organization and institutions to change its culture so as to adapt and take the benefits of adherence to these reporting standards. If organizations or institutions fails to change its culture, then benefits derivable from observing financial reporting standards will not be achieved (Olademeji, 1995). 
INTERNATIONAL JOURNAL OF ACADEMIC RESEARCH IN BUSINESS AND SOCIAL SCIENCES

Vol. 8, No. 8, August 2018, E-ISSN: 2222-6990 @ 2018 HRMARS

\section{Theoretical Framework}

There is no generally accepted theory governing financial reporting disclosure (AL-Shammri, 2005; Schipper, 2007). This study is based on New Institutional Theory. New Institutional Theory has been widely used by various researchers in sociology, political science, business and management as well as information system and technology. The increasing use of institution theory in other research areas is also prevalent over the years. The corner stone year of the new institutional theory would have to be 1977 when John Meyer Published his paper "the effect of education as institution" in the American journal of sociology.

New institutional theory generated new paradigms for understanding how institutional pressures shape organizations and drive organizational change. The foundational pieces of new institutional theory include Meyer and Rowan's 1977 work that argued that formal structure emerges in organizations as these organizations adhere to institutional norms and beliefs from their larger organizational environment. As an organization adopts these beliefs, they become codified into the rules and practices that comprise an organization's formal structure. (DiMaggio and Powell, 1983). In the accounting research area, new institutional theory has been used to explain many case studies in management accounting, auditing and institutional accounting. Accounting as one of the tools to produce information from the organization cannot be separated from the organization norms, value and behaviour. Many longitudinal case study of management accounting use new institutional theory as a powerful tool to understand the behaviour of an organization over time.

\section{Effects Of IFRS Adoption \\ IFRS and Accounting Quality}

Accounting quality, according to Bhattacharjee and Islam (2009) is a function of the firm's overall institutional setting, including the legal and political system of the country in which the firm resides. The adoption of IFRS in Nigeria and beyond is aimed at bringing about accounting quality improvement through a uniform set of standards for financial reporting. Land and Lang (2002) opined that accounting quality has improved worldwide since the beginning of the 1990s and attributed it to factors such as globalization and anticipation of international accounting harmonization. IFRS is contingent on at least two factors. First, improvement is based upon the premise that change to IFRS constitutes change to a GAAP that induces higher quality financial reporting. For example, Barth, Landsman, \& Lang (2006) find that firms adopting IFRS have less earnings management, more timely loss recognition, and more value relevance of earnings, all of which they interpret as evidence of higher accounting quality. Second, the accounting system is a complementary component of the country's overall institutional system (Ball, 2001) and is also determined by firm's incentives for financial reporting. Various literatures document improvements in accounting quality following voluntary IFRS adoption (Barth, et al 2006; Gassen \& Sellhorn, 2006., Hung \&Subramanyam,2007) to reduce information asymmetry between managers and shareholders and it can be evidenced by proper assets and earnings management, lower cost of capital, and high forecasting capability by the investors about firm's future earnings. Barth et al. (2006) suggest that accounting quality could be improved when alternative accounting methods used by managers to manage earnings are eliminated.

\section{The network effects of IFRS}

As quoted in Atu, Raphael and Atu (2013), lyoha and Jafaru (2011) state that many countries adopted IFRS believing that IFRS would create a positive "Network" or "Sociability" effect. The Network effect 
INTERNATIONAL JOURNAL OF ACADEMIC RESEARCH IN BUSINESS AND SOCIAL SCIENCES

Vol. 8, No. 8, August 2018, E-ISSN: 2222-6990 @ 2018 HRMARS

is said to exist where the value of a product or service is expected to increase exponentially when more people use the product or service. Therefore, as more and more countries adopt IFRS, it becomes more appealing to others that are yet to consider the adoption.

\section{Benefits of IFRS Adoption}

Notwithstanding that there may be some challenges to face by countries in their decision to adopt IFRS; its worldwide adoption has been promoted on the premise of its perceived benefits which are considered to outweigh the costs. Proponents of the adoption of IFRS argue that there are a number of benefits which can be gained from greater cross-country comparability of firms' financial reports. Barth (2007), for instance, argues that by adopting a common body of international standards, countries can expect to lower the cost of information processing and auditors of financial reports can be expected to become familiar with one common standard than with various local accounting standards. The argument here is that countries choose to adopt IFRS when they expect to increase the share of foreign capital and trade in the economy. In this sense, even countries with low levels of foreign capital and trade can choose to adopt IFRS if they are expecting growth in those sectors.

\section{Attracting foreign Direct Investment}

With more reliable and credible financial statements, the propensity to attract foreign direct investments will increase as the nation's risk profile would be known and predictable. In other words, investors are attracted to environments where the rewards are high relative to risks. Availability of reliable information contributes to the lowering of this risk (Abel, 2011). This view is in consonance with Okpala (2012) who found out that there is a significant relationship between IFRS adoption by companies and FDI in Nigeria which in turn will improve the economy.

Credible financial information which makes investment decisions efficient, crucially depend on the qualitative and quantitative characteristics of information including relevance, reliability, comparability, understandability, full disclosure of underlying accounting policies, etc. As companies, seek investment opportunities in other countries or within the country, their financial statement must be accurate and comparable across industries and jurisdictions to attract the right investment and financial support. Thus, the goal of credible financial reporting must be pursued conscientiously such that no doubts exist about the quality of the financial statements produced by companies in Nigeria. As Harteneck (1997) observed, in countries where "doubts exist as to the quality, consistency or transparency of their rules, a price must be paid for the shortcomings namely lower market values for their shares and/or higher interest rates for their financing. Also, the cost of raising funds depends significantly on the quality of information available to potential and existing investors as well as the basis of accounting policies applied. Indeed, lack of knowledge of the basis of accounting implies higher risks and higher costs of raising funds. Accordingly, the cost of raising funds will be much lower with IFRS statements. Indeed, the use of IFRS will facilitate greater acceptability of financial reports by regulators and this can enhance secondary listings of companies in global stock markets. Inevitably, local stock exchange will become busier and more active as entities with IFRS-based financial reports continue to attract FDIs.

\section{Bridge Communication gap with Stakeholders}

Accounting and financial information users are numerous so also are their needs different.

Therefore, financial information must be presented in a language that communicates effectively with the various users. IFRS, given its global appeal, enhances this communication with greater 
INTERNATIONAL JOURNAL OF ACADEMIC RESEARCH IN BUSINESS AND SOCIAL SCIENCES Vol. 8, No. 8, August 2018, E-ISSN: 2222-6990 @ 2018 HRMARS

Stakeholders. No conversion is required as the language of preparation is internationally understood by current and potential investors. Okpala, (2012) concluded that the adoption of IFRS will increase the level of confidence of global investors and investment analysts in the financial statements of companies in Nigeria. For the multinational companies, it will help them to fulfill the disclosure requirement for stock exchanges around the world (Armstrong, et al 2007. Covrig, Defond \& Hung 2007).

\section{Uniformity in Accounting Language}

Adoption of IFRS will lead to uniformity in accounting language across the globe which is a pre requites for the globalization of business, finance and investment with primary objective of eliminating the unnecessary complexity that exists with multiple reporting languages. As it is common knowledge, there exist differences in the classifications of financial information, levels of disclosure and accounting concepts between countries. Abel, (2011) opined that accounting terminologies can easily confuse the uninitiated owing to differences in business language. In supporting his view gave an instance on the word stock which, in most North American countries, refers to share ownership, whereas, in the commonwealth countries, the word stock is typically associated with merchandise inventory. The closest word to current in Japanese language is said to be present. While these two words (i.e. current and present) may appear to convey the same meaning, such may not be the case if used in terms of asset valuation in the preparation of financial statements. While current value is about discounted cash flow measures. In this sense, unsold stock may convey under-subscribed floatation. In commonwealth countries, this will refer to unsold inventory of finished goods. Still on current: whereas the time frame distinguishing a current and non-current liability is typically a year in the US and in IFAC standards, the cut-off point is commonly four years in Germany. In fact, Choi (1998) said it succinctly when he observed in his presentation at conference that "Accountants inhabit a kind of Tower of Babel where we not only speak different language but also give different interpretations of the same events and transaction".

\section{Challenges of IFRS Adoption}

Obazee (2007) opined that the principal factors affecting the implementation of IFRS in Europe, America and the rest of the world are cultural issues, mental models, legal impediments, educational needs and political influences in those countries rather than the most widely perceived technical issues. This goes a long way to explain Siaga (2012) statistics which show that despite $40 \%$ of African country having access to IFAC, only $28 \%$ of IFAC members in Africa have adopted IFRS. This then shows that it's not about the technical problem but the other factors as opined by Obazee (2007). This is in consonance with Daske, Hail, Leuz and Verdi (2008) and Ball (2006) Besides there are lots of uneven applications, breeding different IFRS versions (Tsakumis, Campbell \& Douphik, 2009).Nobes (2006) has indicated the motivations and opportunities for different IFRS to continue. There must a coordinated regulatory review and enforcement mechanism to facilitate consistent application. The complexity of certain IFRSs and tax orientation of most nations have been identified as the two most significant impediments to convergence (Larson \& Street, 2004). Other notable challenges include:

\section{Economy}

A significant obstacle to international financial reporting standardization is that accounting regulations whether national or international can and do have economic consequences (Nobles \& Parker, 2004). Governments of different countries may be unwilling to give up control over a process 
INTERNATIONAL JOURNAL OF ACADEMIC RESEARCH IN BUSINESS AND SOCIAL SCIENCES

Vol. 8, No. 8, August 2018, E-ISSN: 2222-6990 @ 2018 HRMARS

which has real economic consequences to an international body over which they have little or no influence.

\section{Politics}

The effect of politics on the adoption and implementation of international accounting standards is directly derivable from the effect of economic factors on accounting regulations. Economic consideration whether on industry- level or at national level reflect on governments' attitude towards international standards, much so as no governments wants to be seen as acting against the interest of those in the position to vote them out of office. Stigler (1971) explains that governments are made up of individuals who are self-interested and will introduce regulations more likely to lead to their reelection. The powers behind standards setting are the special interest groups and lobbyists that could be advocates for the banks, the investors, companies, stakeholders or other political groups or subdivisions (Enofe, 2013). When an important accounting issue is at stake those who are less favored by the outcome of the event turn to lobbyists to seek for redress. In the past, these lobbying groups have put so much pressure on politicians to prevent standard setters from finding adequate solution to important technical accounting problems. While the adoption and implementation of international accounting standards will enjoy faster pace in countries that had closer or similar socio-political culture with the Anglo-Saxon /America countries, the same cannot be expected of former communist and socialist USSR and European countries. Some countries have nationalistic difficulties in abandoning their national standards for foreign ones. This is argued to form the basis of the US and some other countries' lukewarm attitude towards keying in fully into the adoption of international accounting and auditing standards. In the wake of the global market crisis, the European Commission (EU) pushed for the implementation of IFRS.9, valuation of financial instruments. This, according to Enofe. (2013), make the politics of accounting standard setting even more pronounced because while the United States preferred the fair value measurement, the Germans preferred different method because of the negative impact of the fair value measurement on the balance sheet of the major banks in their country.

\section{Culture}

One key factor that adversely affects the adoption and implementation of international accounting and auditing standards is cultural differences, which is differences in accounting reporting culture, language, business tradition, work skill and ethics. An example of this obstacle to harmonization is given by Perera (1989) who, in his assessment of the potential success of transferring accounting skills from Anglo-American countries to developing countries, notes that: The skill transferred from Anglo-American countries may not work because they are culturally irrelevant or dysfunctional in the receiving countries' context. Perera further argues that international accounting standards themselves are strongly influenced by Anglo-American accounting models and, as such, these international standards tend to reflect the circumstances and patterns of thinking in the AngloAmerican group of countries and that these standards are likely to encounter problems of relevance in countries where different environments from those found in Anglo-American countries exist. Continental Europe and indeed most EU countries which includes majority of German companies continue to rely on 'insider' forms of finance, and Roman law system. These kind of accounting regulations will probably be more appropriate for most of these Continental European Countries than the imposition of a form of Anglo-American accounting system. This perhaps informed Nobes and Parker (2004) to suggest that in such circumstances, it might be more appropriate to have a dual 
system where all companies in each country are required to prepare financial accounts in accordance with their historically developed domestic system, and companies which raise funds internationally to prepare an additional set of accounts (probably only the consolidated or group accounts) in accordance with Anglo-American style international accounting rules. Language is also a very important aspect of culture. International accounting and auditing standards are originally written in English language. Adopting and implementing these standards in non-English speaking countries entails first, finding translators who are both sufficiently knowledgeable in the subject matter of accounting and auditing and versed in both the English and the local language. A lot of difficulties arise in getting capable translators and even where they exist, some of the English language terms in the standards sometimes may not have any local language equivalent (McGee, 1999). The translation of the international standards is a major challenge in the adoption and implementation of the standards as translators often find it difficult to convey the real meaning of the English text in the translated standards.

\section{Laws and Regulations}

International Accounting Standards as espoused in IFRS by IASB are principles-based which work within a set of laid down framework. On the other hand, rules-based system regulates issues as they arise. Principles-based system operates within a framework that provides the background of principles within which standards can be developed and the standards so produced are not in conflict with each other. Differences in legal systems and accounting rules among countries have serious implications for the adoption and implementation of accounting standards.

There is a multiplicity of laws and bodies for the regulation of accounting, financial reporting and auditing requirements of companies and other public interest entities in Nigeria, while the main legal framework for corporate accounting and auditing practices in Nigeria is the Companies and Allied Matters Act 2004 (Akhidime, 2010). Strangely, the Nigerian Companies and Allied Matters Act which was last amended in 2007 has remained unchanged to reflect any recognition of IFRS provisions even as IFRS adoption is considered to conflict with some existing Nigerian laws (Izedonmi, 2014). With IFRS conflicting with some of the existing Nigerian corporate financial and auditing laws, the prospect of a smooth transition to IFRS without adequate enforceable statutes remains threatened.

\section{Educational Institution}

No accounting reform Project is complete without upgrading the accounting curriculums of at least some universities in the country (McGee, 2006). Universities and other tertiary educational institutions are considered to be in the best position to take a lead in the provision of needed academic direction and foundation for training of accountants. The implication of this is that lecturers in this institutions are barely knowledgeable of the modalities and workings of IFRS to effectively educate or transfer the skills to others. As a commonly held view, the trainee (student) cannot efficiently become a master if the trainer is not first a master indeed (Garuba and Donwa, 2011). Izedonmi (2014) asserts that only one out of more than two hundred accounting departments of Nigerian Universities and polytechnics has developed the needed curriculum for international accounting and auditing standards (Izedonmi, 2014). The fact that professional accounting bodies require successful education at the tertiary level as pre-requisite for enrolling into their professional examinations underscores the importance of tertiary education which NASB, $(2010, p .19)$ considers "a critical success factor that requires urgent attention". The practical implementation of IFRS understandably therefore, requires adequate technical capacity, particularly among preparers of 
financial statements and auditors. The Committee on Road Map to the Adoption of International Financial Reporting Standards (CRAIFRS), had envisaged that Nigeria may encounter the shortage of accountants and auditors who are technically competent in the implementation of IFRS (NASB, 2010). The latest study of Isenmila and Aderemi (2013), revealed that even after two years into the implementation of the adoption of IFRS in Nigeria, "Tertiary Educational Institutions have not potentially developed enough to support the ongoing mandatory adoption of IFRS". The very weak Nigerian educational system that is ill-equipped and unprepared to provide the required theoretical knowledge that are needed for the production of persons to be trained and absorbed into the membership of local professional accountancy bodies portends great danger to the successful implementation of the adoption of IFRS as there is bound to exist situation where there is lack of the required human capacity to drive the transition to IFRS.

\section{Level of Awareness}

What underscores the low level of awareness by virtually all the stakeholders of IFRS adoption and implementation in Nigeria, in the view of Izedonmi (2014) is the fact that whereas it took the ten (10) leading accountancy bodies 37 years to build the International Accounting Standards, Nigerian opted to implement its adoption after only four (4) years of preparation along an IFRS road map that was designed in 2010. It is therefore, not out of place to consider other challenges against the adoption and implementation of IFRS as likely flowing from the short period it is taking Nigeria to prepare for the transition from GAAP to IFRS. The transition from GAAP to IFRS has serious implications for regulators, users of financial statements, educators, and other stakeholders whose roles in the successful implementation and adoption of the new standards cannot be taken for granted; hence they are required to be appropriately communicated of such implications. While the Committee on Road Map to the Adoption of International Financial Reporting Standards counseled on the need to have a logistical framework of targeted activities aimed at creating awareness amongst the stakeholders (NASB, 2010), it is considered by Garuba (2011) that "most users and even the preparers and assessors of IFRS based accounts such as accountants and auditors have very low IFRS awareness and would find difficulty in understanding, appreciating and to correctly implement what they are not current about or sufficiently aware of".

\section{Professional Accounting Bodies}

Professional accounting bodies have the responsibility of taking a leading role in the orientation of prospective and existing members of their bodies of the demands of IFRS. They have responsibility of giving clear guidance and directions to their members on ways around the difficulties encountered in the application of the standards. However, while much is being done by the two professional accounting bodies in Nigeria, the Institute of Chartered Accountants of Nigeria, ICAN and the Association of National Accountants of Nigeria ANAN, need to upgrade their members knowledge on the requirements of IFRS through Mandatory Continuing Professional Education (MCPE) programmes. These efforts are considered to be largely at pedestal and expository levels that lack sufficient depth to provide the required level of proficiency among both the preparers and auditors of IFRS based financial statements. The poor professional development and professional retooling of the skills of Nigerian accountants and auditors on the workings of IFRS is a disposing factor to the dearth of knowledgeable professionals that are needed to drive the transition to IFRS in Nigeria, hence a potential threat to the successful transition to IFRS. 
INTERNATIONAL JOURNAL OF ACADEMIC RESEARCH IN BUSINESS AND SOCIAL SCIENCES

Vol. 8, No. 8, August 2018, E-ISSN: 2222-6990 @ 2018 HRMARS

\section{External Auditors}

The transition to IFRS based financial reporting and auditing practice poses enormous capacity building and competence improvement challenges to Nigeria's local external auditors, particularly those who are largely engaged in small and medium enterprises. External Auditors operating in Nigeria can be categorized into three group, the first being those from large audit firms especially those from the big 4 international audit firms which audit up to $90 \%$ of listed Nigerian companies and other major Public Interest Enterprises, and second, auditors from large audit firms with international affiliation that audit the remaining 10per cent (World Bank, 2004) and third, auditors from relatively smaller local audit firms that audit Small and Medium Enterprises. While the IFRS skill base and capacity building efforts of the big audit firms (who are credited to have participated in setting up IFRS) adequately march the demands of IFRS, the same cannot be presumed for local Nigerian external auditors who understandably lack sufficient international exposure and the financial capacity to fund extensive training and retraining for themselves and their staff on the reporting demands of IFRS. The study of Isenmila and Aderemi (2013) confirms this position by concluding that Nigerian "local audit firms lack the expertise to foster the smooth transition to IFRS". The inadequacies of local external auditors have far reaching implications for the successful implementation of IFRS for Small and Medium Scale Enterprises whose Accounts are prepared and audited largely by local accountants and auditors, unlike the quoted companies and other public entities that are largely audited by better exposed and trained accountants and auditors from international audit firms.

\section{The Way Forward}

Effective implementation of IFRS requires careful planning and extensive public education, the allocation of resources, a legal and regulatory support system and institutional support with strong management systems. Unless the various stakeholders are integrally involved and included in development plans and how they are affected, they will be reluctant to support the change and IFRS adoption may not succeed.

The timeline for the full adoption which this paper consider too short should be elongated as it is obviously impracticable for Nigeria to transit from GAAP to IFRS within 4 years, what took industrialized countries about 37 years to gestate. Implementation of certain requirements of IFRSs should be a gradual process because adopting IFRSs is not just an accounting exercise but transition that requires that everyone concerned has to learn a new language and new way of working. In fact, implementation of IFRS is not a one-time process, but rather an on-going effort that requires continued institutional support.

There is the urgent need for all the relevant Nigeria educational institutions and professional accounting bodies to integrate IFRS into their curriculum and the membership qualifying examination syllabi respectively. This should be followed by increased funding by way of special research grants by the government for the training of lecturers on IFRS as a way of building human capacity in support of the transition from GAAP to IFRS.

The two Nigeria's professional accounting bodies, ICAN and ANAN, should of necessity deepen their Mandatory Continuing Professional Education programmes on IFRS and possibly re-accredit all its members on the basis of IFRS compliance. Successful implementation of IFRS needs extensive and on-going support from professional accounting bodies like Institute of Chartered Accountants of Nigeria (ICAN).They can contribute to the effective implementation of IFRS through requirements that hold their members responsible for observing due care in implementing these standards 
INTERNATIONAL JOURNAL OF ACADEMIC RESEARCH IN BUSINESS AND SOCIAL SCIENCES

Vol. 8, No. 8, August 2018, E-ISSN: 2222-6990 @ 2018 HRMARS

All Nigeria's corporate financial reporting statutes should be reviewed with the objective of identifying those in conflict with IFRS and amended and harmonized to conform to the demands of IFRS.

Introduction of an awareness programme by government to improve the degree of compliance with accounting requirements by specified business enterprises. Regulatory agencies in Nigeria like the CBN, ICAN, FIRS, SEC and NSE should work jointly to design an awareness programme on the importance of compliance with accounting requirements of IFRS.

\section{Conclusion and Recommendations}

There is no doubt that conversion to IFRS in developing countries is a huge task and a big challenge; however like we earlier said adoption and implementation of IFRS should be on the basis of costbenefit analysis, it should not be a decision based on following the crowd. The consideration of the following recommendations by the relevant arms of the government is considered pertinent if Nigeria is to truly and fully transit to IFRS and conform to best global practice in corporate financial reporting:

Based on studies undertaken on IFRS adoption in Nigeria the following recommendations are hereby advanced:

(i) Strengthen professional accounting education and training.

(ii) Strengthen capacity of the regulatory bodies and review adequacy of statutory enforcement provisions.

(iii) Raise awareness of professionals, regulators and preparers to improve the knowledge gap. (iv) Establish an independent body to set monitor and enforce accounting and auditing standards and codes.

(v) Adequate resources should be put in place to support the sustainable implementation of IFRS. This includes having consultative groups available to respond promptly to concerns by users and to provide for their ongoing training.

\section{References}

Abel, A.A. (2011). Imperative of the new reporting framework. The Official Journal of The Institute of Chartered Accountants of Nigeria, 44(4), 17-25.

Aghator, G.E., \& Adeyemi, B. (2009). Comparative study of accounting standards in Nigeria: concepts and issues. Journal of Advanced Management Sciences, 2 (1), 72-75.

Ahmed, A. (2003). The influence of IFRS implementation on business management. Journal of Accounting and Business Management, 2(4) 35-48.

Akhidime, P.O. (2010). An international IFRS comparison. Journal of Finance, 59(2), 537-545.

AlShamiri. A. (2005). International convergence of accounting practices. Journal of Resources Development and Management, 5(3) 16-22.

Armstrong, C., Barth, M., Jagolinzer, A \& Riedi, E. (2007). Market reaction to the adoption of IFRS in Europe (Working paper), Stanford University. 
INTERNATIONAL JOURNAL OF ACADEMIC RESEARCH IN BUSINESS AND SOCIAL SCIENCES

Vol. 8, No. 8, August 2018, E-ISSN: 2222-6990 C 2018 HRMARS

Atu, R. (2013). The effect of mandatory IFRS adoption. International Journal of Marketing and Economics. 4 (2), 15-23.

Ball, R., Robin, A., \& Wu, J.S. (2003). Incentives vs standards: Properties of accounting income in four East Asian countries. Journal of Accounting and Economics, 29, (2) 1-51

Barth, M.E. (2007). Research standard setting and provisioning between IFRS and prudential guidelines. Global Journal on Accounting and Finance, 12(3), 15-26.

Barth, M., Landsman, W.R. \& Lang, M.H (2008). International financial reporting standards (IFRS) and accounting quality. Journal of Accounting Research, 26(3), 16-23.

Choi, F.D.S. (1998). Global consequences of international accounting diversity. Accounting and Business Journal. 7(3), 16-22.

Covrig, V., Defend, M., \& Hung, M. (2007). How bias, foreign mutual funding holdings and the voluntary adoption on International accounting standards. Journal of Accounting Research, 45,(2), 41-70.

Daske, H., Hal, L. Leuz C., \& Verdi, R. (2008). Mandatory IFRS reporting around the world: early evidence on the economic consequences. Journal of Accounting and Research 46(5) 1085-1142.

DiMaggio, C., Paul J., and Walter W. P. (1983). The Iron Cage Revisited: Institutional isomorphism and collective rationality in organizational field. American Sociological Review. 48: 147-160.

Enofe, E.E. (2013). International convergence of accounting practices. Journal of Accounting Research, 26(3), 24-33.

Ezeani, N.S. \& Oladele, R. (2012). Adoption of international financial reporting standards (IFRS) to enhance financial reporting. Arabian Journal of Business and Management Review. 2(3), 10-16.

Garuba, A.O; \& Donwa, P. (2011). The challenges of adopting international financial reporting systems in Nigeria. JORIND 1(9). 313-317.

Gassen, P., \& Sellhorn, A.S. (2006). International financial reporting standards and experts' perceptions of disclosure quality. International Journal of Research in Commerce and Management 2(1), 40-46.

Harteneck, (1997). International financial reporting standards as a tool for cross border financial reporting. Mediterranean Journal of Social Sciences. 4 (1), 65-84.

Healy, P.M., \& Palepu, K.C. (2001). Information asymmetry, corporate disclosure and the 
INTERNATIONAL JOURNAL OF ACADEMIC RESEARCH IN BUSINESS AND SOCIAL SCIENCES Vol. 8, No. 8, August 2018, E-ISSN: 2222-6990 @ 2018 HRMARS

capital markets: a review of the empirical disclosure literature. Journal of Accounting and Economics, 31(2), 405-440.

Hung, M., \& Subramayan, K.R. (2007). Financial statement effects of adopting international accounting standards: the case of Germany. Review of Accounting Studies, 12(4), 623-657.

Isenmila, P.A., \& Aderemi, K.A. (2013). Mandatory adoption of international financial reporting standards (IFRS) in Nigeria: the unresolved institutional question. Mediterranean Journal of Social Sciences. 4 (1) 175-184

Iyoha, F.O., \& Faboyede, S.O(2011). Adopting International financial reporting standards (IFRS). A focus on Nigeria. International Journal of Research in Commerce and Management 2(1), 35-40.

Iyoha, F.O. \& Jafaru, J.(2011). Institutional infrastructure and adoption of International financial reporting standards (IFRS) in Nigeria. School of doctoral studies (European Union) Journal. 2011.

Izedonmi, P.A (2014). Adoption of international financial reporting standards and corporate governance. Journal of International Accounting, and Finance, 3(2), 80-89.

Landsman, M., \& Lang, P. (2002). Tax implications of IFRS adoption. Journal of International Accounting, Auditing and Taxation 1(3), 16-22.

Larson, R.K., \& Street, D.L (2004). Convergence with IFRS in an expanding Europe: Progress and obstacles identified by large accounting firms survey. Journal of International Accounting, Auditing and Taxation 1(3), 89-119.

McGee, G. (1999). The impact of national influence on IFRS adoption. International Journal of Research in Commerce and Management 2(1), 35-40.

Meyer \& Rowan, (1997). Adoption of international financial reporting standards in developing economies. Australian Journal of Business and Management Research, 2(5), 32-44.

Nobes, A.O. (2006). The survival of international differences under IFRS: Towards a research agenda. Accounting and Business Research, 36(3), 233-245.

Nobles \& Parker, (2004). The impact of international financial reporting standards adoption on firms. International Journal of Accounting, 1(2), 16-40.

Nwabueze, A.A (2012). Adoption of IFRS and global capital market integration. International Journal of Research in Commerce and Management 3(2), 36-44.

Obazee, J.O. (2007). Current convergence efforts in accounting standard setting and financial reporting: Lagos, Nigeria Accounting standard board. January 31. 
INTERNATIONAL JOURNAL OF ACADEMIC RESEARCH IN BUSINESS AND SOCIAL SCIENCES

Vol. 8, No. 8, August 2018, E-ISSN: 2222-6990 C 2018 HRMARS

Odia, J.O., \& Ogiedu, K.O (2013). IFRS Adoption, Issues, challenges and lessons for Nigeria and other Adopters. Mediterranean Journal of Social Sciences, 4(3), 389-399.

Okpala, K. (2012). Adoption of IFRS and financial statements effects: The perceived implication on FDI and Nigeria Economy. Australian Journal of Business and Management Research, 2(5), 76-83.

Oladimeji, P. (1995). Adoption of IFRS and Nigeria's financial reporting framework. Journal of Accounting and Research 46(5) 1143-1150.

Penman, S.H. (1984). Effect International Financial reporting standards on manufacturing firms. Mediterranean Journal of Social Sciences. 6 (1), 70-88.

Schipper, T. (2007). Challenges in the implementation of IFRS in developing countries. Journal of Accounting and Finance 4(5) 110-123.

Siaga, S.F (2012). Challenges to the adoption of International Financial Reporting Standards in Africa. International Journal of Research in Commerce and Management 3(1), 50-69.

Stigler, A.O. (1971). Impact of IFRS adoption on financial statements of firms. International Journal of Marketing and Economics. 3 (2), 44-59.

Tsakunmis, G.T. Campbell, D.R. \& Douphik, T.S(2009). IFRS: Beyond the standards. Journal of Accountancy, 207 (2) 34-39. 